\title{
Exploration of the Online and Offline Mixed Teaching Model in the College English Teaching
}

\author{
Xue Yan, Haibo Wang \\ Panzhihua University, Panzhihua, China \\ Email: wanghaibo004@qq.com
}

How to cite this paper: Yan, X., \& Wang, H. B. (2021). Exploration of the Online and Offline Mixed Teaching Model in the College English Teaching. Creative Education, 12, 2575-2579.

https://doi.org/10.4236/ce.2021.1211192

Received: October 9, 2021

Accepted: November 14, 2021

Published: November 17, 2021

Copyright (๑) 2021 by author(s) and Scientific Research Publishing Inc. This work is licensed under the Creative Commons Attribution International License (CC BY 4.0).

http://creativecommons.org/licenses/by/4.0/

\begin{abstract}
College English is one of the important basic courses in colleges and universities. The traditional teaching has been adopted in English teaching for many years, which is not ideal and there are some limitations to some extent. With the development of Internet, the traditional teaching should be changed, and the blended teaching concept should be introduced into teaching to improve teaching methods, optimize teaching content, and make use of rich teaching resources to achieve the best blended teaching online and offline and improve the teaching effect of English courses.
\end{abstract}

\section{Keywords}

College English, Online and Offline, Mixed Teaching

\section{Introduction}

With the rapid development of the Internet, multimedia technology has become a common teaching tool for college English teachers. Learning is no longer simply a mode of teaching students by teachers. Instead, the passive learning mode of traditional classroom centered by teachers has been transformed into a mixed learning mode combining online (teaching platform) and offline (classroom teaching).

Michael B. Horn (2015) thinks that blended teaching combining online and offline is "a learning environment that combines face-to-face teaching with teaching based on technology media". The teaching method of using network teaching resources to carry out teaching activities can be combined with traditional classroom teaching, thus providing more possibilities and interests for college students' English autonomous learning. 


\section{Problems in College English Teaching}

In college English teaching, some teachers adopt a single traditional teaching mode, which is mainly taught by teachers and supplemented by students' learning. Because there are many contents in college English, a single classroom blackboard writing cannot be vividly presented. For example, learning a word is difficult for students to master if they rely on the teacher's explanation and write examples on the blackboard. Although some teachers use multimedia equipment to assist teaching with courseware, the courseware is not elaborate enough to effectively assist teaching. Teachers only use traditional classroom teaching methods, which are not combined with modern information teaching methods. Some teachers mainly teach textbooks, and the knowledge associated with them has little or no expansion. As a result, students can't understand the purpose and importance of learning college English. In addition, there are a large number of students in college English classes, which makes teaching management relatively difficult.

The main contents of college English learning are listening and speaking, reading, composition and translation. If the teaching mode is monotonous, students will be distracted in class, the classroom atmosphere will be deserted and the teaching effect will be poor. College English is a public course, which involves a wide range of knowledge. If you don't do a good job in college English teaching reform, it will definitely affect students' mastery of English, thus affecting their interest and enthusiasm in learning college English.

\section{Advantages of Online and Offline Hybrid Teaching}

In the research of domestic scholars, Chen et al., (2018) explained the mode of interactive learning combined with online and offline hybrid teaching. Xing Lili (2020) conducted an empirical study on hybrid teaching combining online and offline based on precise teaching.

One of the main features of the online and offline hybrid teaching mode is that it can improve students' subjective initiative and ensure that students can think independently when they study. Therefore, when applying the hybrid teaching mode, college English teachers must pay attention to students' independent thinking, so that the hybrid teaching can truly reflect its own advantages. College English teachers can use some software to teach students mobile English, and students can also use mobile terminals for fragmented learning. Teachers are mainly responsible for answering questions and checking students' mastery in the offline classroom, so that students play a more leading role in the classroom.

In recent years, domestic scholars Zhu Zhiting and Peng Hongchao (2016) have studied the vitality of precise teaching supported by Internet technology. Online classroom is a supplementary means of offline classroom. Because of the comprehensive requirements of students' listening, speaking, reading and writing, offline classroom time is limited, so online classroom can be used as a sup- 
plementary means of offline classroom to give full play to its advantages. For example, teachers can record in advance or provide students with some network resources in class, so that students can watch after class in the form of homework, and preview or review the cultural phenomena in an English-speaking country in advance. In class, the teacher will give supplementary explanations according to students' homework feedback.

The online and offline hybrid teaching integrates the online learning mode, which is mainly for students' self-learning in the pre-class stage, such as online learning content of small videos. Students' self-learning is adopted before class, so that students can find a more comfortable environment to study according to their own needs, which is convenient for students to master the pre-class video knowledge efficiently. Class teaching also reduces the teacher's blunt explanation process, because students are prepared in advance, teachers and students will increase more interaction and humanistic care in the discussion of related issues, not just the process of students' passive acceptance in class time, which is more convenient for students to use their imagination, enhance students' independent thinking ability, improve learning quality, improve students' independent learning ability, and solve many unsolvable problems in traditional teaching.

\section{Combination of Online and Offline Teaching}

The most obvious feature of the online and offline hybrid teaching mode is that it can fully demonstrate students' subjective initiative. Only when students consciously think and explore problems in the process of English learning can they really improve their learning efficiency.

The online and offline blended learning method enriches the teaching resources, greatly enriches the teaching plan content of college English, and makes the teaching content colorful.

Teaching example 1: when English teachers aim at the teaching content of Wedding, they should let students discuss the Wedding customs and experiences they have learned, collect wedding related contents on the internet, guide students to carry out relevant interactive communication, and then guide students to read and analyze this article consciously, and discuss questions about where, what, how, why and how about together, so that students can understand the writing of this article. Through this interactive link, students can not only improve their English comprehension ability when communicating with others, but also effectively stimulate students' interest in English learning.

Teaching Example 2: In the teaching of Food, the teacher selected some food videos according to the teaching content through the multimedia platform of college English teaching to create the learning environment of this unit, simulate the real language communication environment, and arouse students' enthusiasm and interest in learning. Because before teaching, students have helped themselves with the video clips of related studies, teachers focus on explaining and training many common sentence patterns and knowledge points in Food in 
teaching. When students can clearly understand the common sentence patterns in Food, teachers also need to create relevant language communication environment for students, and help students to use and master these sentence patterns in the environment. Therefore, teachers can choose some pictures of delicious food or video clips of national specialties for students to practice one-on-one group dialogue and explain and talk to the video teaching content, so as to improve students' English verbal communication ability. At present, the teaching resources on the platform of college English education in colleges and universities are rich and colorful, which can not only meet the needs of teachers in class to choose teaching materials, but also provide rich and colorful learning materials for students' self-study.

Teaching Example 3: Taking Readings from Literature as an example, a student downloaded the Fate video of folk tales and directly added it to the extended materials, saying that he was inspired by online learning resources, specially consulted the related materials of folk tales, posted posts to share his learning gains, and expressed his hope to make progress with his classmates. Students become the demanders of learning resources, which also encourages them to think from different angles and improves their initiative in learning English.

\section{Comprehensive Teaching Evaluation Mechanism}

The traditional teaching evaluation method is composed of the final exam result and the usual result, and most of them pay attention to the final result. At ordinary times, grades are only a comprehensive evaluation of attendance, classroom performance, homework, etc., lacking dynamic attention and evaluation of students' learning process, and failing to reflect students' actual learning situation and learning effect timely and accurately.

Therefore, in the traditional classroom teaching, the content of teachers' lectures generally only focuses on the contents of textbooks, which can't supplement and expand the knowledge related to content application for students, and teachers can't assess students' actual English language ability.

However, in the online and offline mixed teaching mode, teachers can make use of the mixed teaching tool-Superstar Learning Pass, which not only distributes learning materials, arranges pre-class preview tasks and homework after class, but also has various classroom activities, such as check-in, questioning, testing, voting, group activities, etc., and all activities can export detailed records. Teachers can use the data provided by the online teaching platform (accompanying classroom or Tsinghua English Online) to know about students' self-preparation before class (Superstar Learning Pass), listening development after class (U campus) and oral English learning (setting up an exclusive morning reading camp to read and punch cards every morning); teachers can use the data of Correction Network (pigai.org) to understand students' after-school translation and composition test, and master the skills of Chinese-English trans- 
lation, the writing format of paragraphs and the writing methods of related topics, so as to accurately grasp each student's learning attitude and the actual effect of English learning. For students with poor English foundation, micro-video explanation can be used to help students learn and improve their interest in learning. From the above teaching situation, each online platform has played its own role well, and has well realized all the teaching links before, during and after class. According to the evaluation, teachers can adjust the teaching scheme, which is conducive to the improvement of teaching methods and teaching quality, thus enhancing the teaching effect.

\section{Conclusion}

To sum up, compared with the traditional teaching mode, the online and offline mixed teaching mode can show more advantages, effectively expand learning time and space, and improve teaching quality. Online classroom and offline classroom should be combined together, and both are indispensable. Only in this way can college English teaching take on a new look, enable students to learn the contents of teaching materials, turn what they have learned into their own abilities, and truly realize the combination of theory and practical application. College English teachers should not only stick to one teaching method, but also keep pace with the times and brainstorm ideas to provide new ideas for the reform of college English teaching.

\section{Conflicts of Interest}

The authors declare no conflicts of interest regarding the publication of this paper.

\section{References}

Chen, C. H., et al. (2018). Research and Practice of Hybrid Teaching Mode Based on Knowledge Construction and Interactive Learning. China University Teaching, No. 8, 33-37.

Horn, M. B. (2015). Heather Staker. Blended Learning: Promoting Educational Revolution with Subversive Innovation. Machinery Industry Press. (Nie, F. H., \& Xu, T. Y. Trans.)

Xing, L. L. (2020). Construction and Empirical Study of Blended Teaching Mode Based on Precise Teaching. China Audio-Visual Education, No. 9, 135-141.

Zhu, Z. T., \& Peng, H. C. (2016). Efficient Knowledge Teaching Supported by Information Technology: Stimulating the Vitality of Precise Teaching. China Audio-visual Education, No. 1, 18-25. 